\title{
SYNTHESIZING STRUCTURATION AND INSTITUTIONAL THEORY: THREE CASES
}

\author{
Jason Bennett Thatcher \\ College of Business \\ Florida State University \\ Tallahassee, FL 32306-110 \\ Telephone: (850) 644-0916 \\ Fax: (850) 644-8225 \\ E-Mail: jthatche@mailer.tsu.edu \\ Mark Srite \\ School of Business Administration \\ University of Wisconsin - Milwaukee \\ P.O. Box 742 \\ Milwaukee, WI 53201 \\ Telephone: (414) 229-5502 \\ Fax: (414) 229-5999 \\ E-Mail: msrite@uwm.edu \\ Manolis Diakourakis \\ College of Business \\ Florida State University \\ Tallahassee, FL 32306-110 \\ Telephone: (850) 644-0916 \\ Fax: (850) 644-8225 \\ E-Mail: edd3323@gamet.acns.fsu.edu \\ David Kuhlmeier \\ College of Business \\ Florida State University \\ Tallahassee, FL 32306-110 \\ Telephone: (850) 644-4417 \\ Fax: (850) 644-8225 \\ E-Mail: $\underline{\text { dbk9613@gamet.acns.fsu.edu }}$
}

\begin{abstract}
Research suggests that it is difficult to predict the influence of information technology (IT) on organizations. Using the structuration approach, theorists like Orlikowski suggest technology's effect is context dependent. Within organizations, structuration theory suggests IT's use and understanding reflects the interaction of individuals, social structures, and features of the technology. However, in the public sector, external institutions play an important role in shaping the development of internal structures. This paper develops a conceptual framework that links institutions and organizations social structures to the use and understanding of information technology in the public sector. To develop a more accurate image of the structuring process, it suggests theory should explicitly model the influence of regulative, normative, and cognitive institutions on how technology is used and perceived in government organizations.
\end{abstract}

\section{MODELING TECHNOLOGY IN PUBLIC ORGANIZATIONS}

Since the early Nineties, reformers have advocated using information technology (IT) as a means for enabling citizen participation and effectively managing information. For example, when Florida was experimenting with absentee voting over the Internet, Sandra Mortham, then Secretary of State, suggested the electronic voting initiative would guarantee citizens the "opportunity to fully participate in Florida's democracy" (Florida Department of State 1997). Due to perceived benefits, advocates contend that public agencies should invest in technologies and re-engineer processes (Gore, 1993).

Despite huge government investments in IT, public information systems often fail to realize projected benefits (Madden and Miranda, 1998). A notable example occurred in 1985 when the Internal Revenue Service's computer system faltered under its workload and failed to process tax returns (Kelman, 1990). When explaining systems' inadequacy, critics frequently point to features of public organizations like procurement systems and their institutional context such as legislative oversight (e.g. Gore 1993). They suggest that the institutional and organizational environment limits the efficacy of IT in the public sector.

Given IT's potential for improving public sector service delivery, it is important to understand how the organizational and institutional context affects the understanding and use of IT within public agencies. The purpose of this paper is to present a conceptual model linking institutions, social structures, and technology in public organizations. First, it briefly reviews support for deterministic views of IT-induced change in public agencies. Next, the paper outlines how the structuration approach informs our understanding of the implications of information technologies. Then, it extends the structuration approach to the public context. Finally, through a 
brief review of three cases, the paper illustrates how institutions influence the social structuring of information technologies within government and non-profit organizations.

\section{GOVERNMENT AND TECHNOLOGICAL CHANGE}

Advocates of public sector reform emphasize information systems' (IS') role in improving public organizations' responsiveness to their clients' needs (Anderson and Danziger, 1995). Osbome and Gaebler (1993) suggest that modern "hierarchical, centralized bureaucracies . . . simply do not function well in the rapidly changing, information-rich, knowledge intensive society and economy of the 1990s" (p. 12). Through strategic applications of IS, they assert that leaders may build organizations capable of responding to dynamic environments and of meeting changing client expectations. The National Performance Review (Gore, 1993) echoes this logic. It suggests that positive reforms hinge on how managers implement new technologies and change processes in public agencies. If they adopt an IT, reformers assert that public agencies will become more efficient, effective, and customer oriented.

However, research suggests that IT's introduction and use does not necessarily lead to more efficient public organizations. In the URBIS studies, Danziger, Dutton, Kling, and Kraemer (1982) found that public organizations used IT to supplement, not reengineer, existing processes. In the context of mainframe computing, IT was used to automate data management systems. Although the technology was new, processes were not fundamentally altered. Indeed, IT may reemphasize the need for hierarchical structures (Gurbaxani and Whang, 1991). IT use increases available information and complexity in the organization and environment. To navigate complex situations, firms will require more middle managers to coordinate a firm's activities (Wynne and Otway, 1983). Clearly, IT use may not yield organizational change.

Towards A Dynamic Model: The Structuration Approach

Given unanticipated results, theorists have sought more dynamic explanations of technology's influence on organizations. When compared to deterministic approaches, researchers (e.g. Orlikowski, 1992; DeSanctis \& Poole, 1994) suggest that using structuration theory to examine information technology yields a broader understanding of IT's influence within organizations. Emergent approaches, such as structuration, suggest ITlinked outcomes reflect the interaction of diverse environmental features such as organizational culture and a technology's attributes.

\section{STRUCTURATION THEORY: A BRIEF REVIEW}

This section briefly reviews structuration theory and its applications to the understanding of IT within organizations. It suggests that integrating institutional and structuration approaches will yield a deeper understanding of the social structuring of information technologies within organizations.

Structuration theory provides a dynamic explanation of how humans construct and interact with their environment. Within organizations, social structures may be perceived as rules or norms that guide human understanding and action. They are created by the interaction of human action, existing social structures, and artifacts such as IT (Giddens, 1979). Social structures should be perceived as ways of understanding that persist over time. They define parameters of human interaction and applications of knowledge within organizations. (See Orlikwoski (1992) for a more detailed review of structuration theory).

Structures are transitory in nature. At any given moment, people, rules, and resources interact as part of a recursive process (DeSanctis \& Poole, 1994). A structure may be reshaped, reinforced, or undercut by changing perceptions, technologies, or experiences. Giddens (1979) suggests that structures should be perceived as having a dualistic nature in that they enable and limit human action. Consider a group. Values and understanding embodied in structures shape group decision-making processes. By shaping group processes, structures limit choices. Simultaneously, they allow group members to organize and make sense of information. By doing so, they enable group decision making processes and legitimize ensuing actions.

Within organizations, structuration theory suggests IT's influence reflects interacting social structures. Outcomes are a product of the recursive interaction of an organization's structures, individuals' understanding, and an artifact's features (Orlikwoski, 1992). An organization's formal and informal structures such as the division of labor, decision-making processes, or experiences influence how individuals perceive and select a technology. Once they adopt an IT, individuals' use of a technology's features contributes to new social understanding. In turn, the newly enacted social practices shape the organization's structural features. Through users, organizational structures and technology interact. At any given point in time, the interaction between individuals and structures contributes to shifting definitions and perceptions of the technology's potential. As use of a technology shifts, users' perceptions and structures change. Within this model, users mediate the interaction of technology and an organization's structure. Research using the structuration approach has emphasized endogenous determinants of technology use in organizations. Throughout their work, leading "structuration theorists" like Orlikowski $(1991,1992)$ and Barley (1986) have consistently emphasized the importance of 
structures within groups and organizations.

\section{INSTITUTIONS AS SOCIAL STRUCTURES}

When exploring the structuring of technologies, scholars have left relatively unexplored the broader institutional context in which organizations are embedded (King et al 1994). Institutional theory examines how organizations' choices and their understanding are influenced by the social structures embedded in the environment (Scott, 1995). Not unlike internal structures, institutions reflect external "rules, norms, and beliefs that describe reality for the organization, explaining what is and what is not, what can be acted upon and what cannot" (Hoffman, 1999, p. 351). Scott (1995) suggests institutions may be comprised of three distinct types of social structures: regulative, normative, and cognitive. Regulative features build on laws and regulations. Organizations comply with regulative institutions to avoid punishments such as lawsuits. Normative institutions reflect the social understanding embedded in decision-making rules or procedures. Organizations comply with these rules to meet perceived social obligations rooted in external value systems such as professional codes of ethics. Cognitive institutions embody the symbols and cultural understanding of reality and the frames "through which meaning is developed" (Hoffman, 1999, p. 353). Social structures are cognitive institutions embedded in firms and broader organizational fields. As a group, regulative, normative, and cognitive institutions frame how issues and artifacts are understood and used in organizations (Fligstein, 1990).

\section{EXTENDING STRUCTURATION THEORY TO THE PUBLIC CONTEXT}

When applied to public organizations, structuration-based models of technology need to explicitly link the broader regulative, normative, and cognitive structures to internal "social structuring" (see Figure 1). Laws, which can be seen as regulative features, often dictate specific processes for planning, purchasing, and implementing new information technologies. Normative features can be seen through limited empirical evidence which suggests that, in comparison to private firms, public agencies' use of information technologies reflects more extensive political interdependencies, more "red tape", purchase decisions more concemed with due process than the "bottom line", more external budgetary constraints, and information management positions situated lower in the organization (Cats-Baril \& Thompson, 1995; Caudle, Gorr, \& Newcomer, 1991). These results generally support the proposition that the use and understanding of information technologies reflects the degree of discretionary authority extended to managers (Kraemer, 1989). Finally, organizational "publicness," that is, the extent to which the organization's activities are owned, funded, and overseen by legal governmental authority rather than market forces (e.g., Rainey, Backoff, \& Levine, 1976), influences the development of cognitive institutions, i.e. social structures, within organizations.

Within the public sector, regulative institutions shape structures of domination linked to information technology. In terms of domination, regulative institutions assign decision-making authority for developing strategic IT plans and acquiring technology. For example, in Florida, a central coordinating agency (State of Florida Technology Office, 1997) guides public technology policies. The coordinating agency's authority is rooted in Florida Statutes. Also, legal institutions articulate rules for the formal technology acquisition processes. For example, in federal agencies, statues spell out requirements for request for proposals, decision-making criterion, and appropriate payment methods for purchasing information systems (Kelman, 1990). Further, laws underpin perceptions of appropriate uses of information technology. For example, Florida public employees are expected to restrict Internet use to work-related activities. In numerous cases, employees have been sanctioned or fired for violating guidelines on appropriate uses of technology. Clearly, regulative values constrain selection decisions and the range of applications of information technology within public organizations. 
Figure 1.

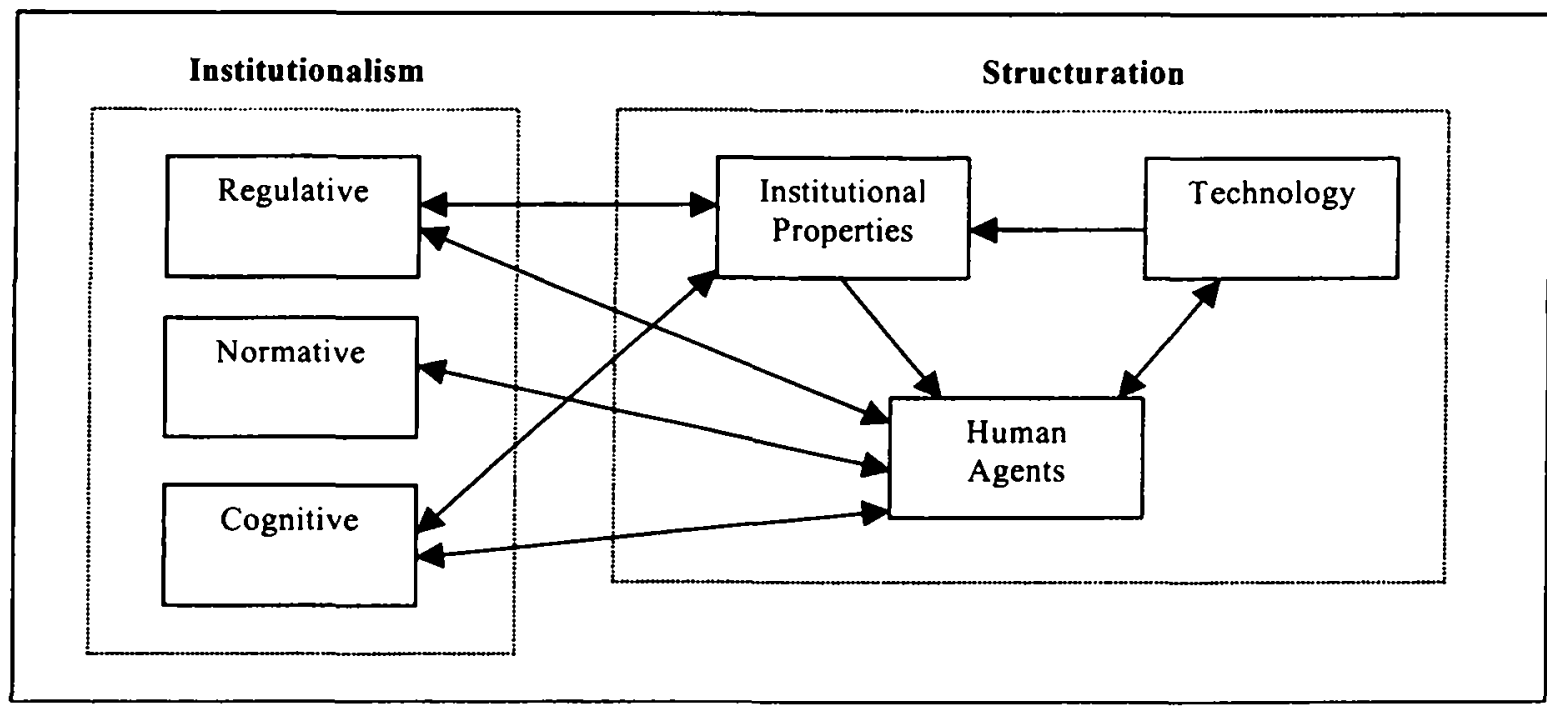

It is important to note that structures and events within organizations influence the broader institutional framework. For example, during the late 1800 s, perceived abuse of purchasing systems by public officials led to the strengthening of institutional controls over the purchasing and hiring processes (Kelman, 1990). Critics suggest that institutional controls have undercut agencies' ability to purchase cutting edge technologies or to develop ongoing relationships with vendors (Globerman and Vining, 1996). Due to constraints, they suggest agencies have not been able realize the perceived efficiencies linked to IT use. As a result, reformers have called for the loosening of regulative controls on IT purchasing.

Normative institutions can be seen to influence structures of legitimation linked to information technology. Many scholars suggest that employees in the public and nonprofit sectors are motivated differently than their private sector counterparts (Perry, 1997). They suggest that values such as equity concern for client needs, or service shape civil servants' behavior (Perry, 1990). When evaluating IT, normative institutions will influence the perceived legitimacy of information systems. Consider the role of stakeholders in evaluating system performance. In New Zealand, despite realizing economic efficiencies, stakeholder criticism led the Department of Education to abandon a successful payroll processing system (Myers, 1994). Reflecting normative values, public employees' obligation to respond to stakeholders played an important role in de-legitimizing an information system within the agency.

Cognitive institutions influence structures of signification within organizations. Scholars suggest that information technology use may parallel shifts in broader cultures (Fletcher and Taplin, 1999) and governments (Norris and Kraemer, 1996). Consider information systems design. In a comparative study of Scandinavia and the United States, Kraemer, Anderson, and Perry (1994) found approaches to design reflected cultural differences across countries. In Scandinavia, information systems were designed to meet needs across agency and government boundaries. Within the United States, public information systems' development reflected distinct environmental pressures felt by different agencies. Cognitive institutions influenced the development of distinct system design processes and outcomes. Where Scandinavian agencies emphasized values such as consistency and gradual development, U.S. agencies information systems' development processes reflected values such as responsiveness and stakeholder participation in defining organizational needs. In either country, cognitive values shaped perceptions of appropriate organizational rules for systems design.

\section{IMPLICATIONS OF INSTITUTIONS AND STRUCTURATION APPROACH: THREE WEB DEVELOPMENT CASE STUDIES}

In this section, structuration theory is used to extend our understanding of institutions' influence on IT use in the public sector. Three cases are used to illustrate the influence of institutions on the social structuring of Internet technologies within organizations. To protect the anonymity of the organizations, pseudonyms have been used in each case.

\section{Case One: Regulative Institutions and Website Design}

Florida possesses among the most rigid right to information and access laws in the United States. The Sunshine Laws require two essential tasks: information provision and notification of meetings. Chapter 119 of the Florida 
Statutes requires any record created or received by publicly commissioned agencies while conducting official business to be available for review unless specifically exempted by the Legislature. The definition of public records includes paper and electronic documents including sound recordings, electronic communications, and photographs (Florida Attorney General 1997b). Chapter 286 of the Florida Statutes establishes the right of access to most board, commission, or other public governing body meetings (Florida Attorney General 1997a). Public organizations are required to provide access to any meetings where two or more governing members will discuss business.

Florida agencies' application of Internet technologies reflects political leaders' legal authority and stringent information provision requirements. OVERSIGHT is a regulatory commission charged with overseeing the service delivery of a large state-agency. They are charged with responding to citizen concerns, monitoring compliance with operating standards, and evaluating a large state agency's performance. Within OVERSIGHT, regulative institutions shaped the acquisition process and the features of their proposed Website. The impetus to develop a site stemmed from the legal authority vested in board members. The politically appointed chairman directed staff to contract out the design and implementation of the Website. They were instructed to develop a site that notified stakeholders of meetings and provided documents such as minutes, press releases, and reports.

Reflecting Sunshine Law requirements, OVERSIGHT staff established three criteria for evaluating the Website's design. To ensure compliance with information provision requirements, the staff wanted a wide range of users to be able to access information. The Website had to be easily navigable via a wide range of browsers ranging from text-based browsers such as Lynx to graphical browsers such as Netscape. Also, to ensure that reports could be viewed and printed by stakeholders, the staff required reports to be provided as text-based and through widely available document readers such as Adobe Acrobat or Microsoft Word. To ease compliance with notification requirements, the staff wanted an easily updated site. Clearly, the site's evaluation reflected information provision and notification requirements.

As implemented, the Website's simplicity reflected the staff's concern for ease of access and use. To ensure compatibility with a wide range of browsers, important links were provided in text and image based formats. To broaden access, important documents such as meeting notifications were posted in a text-based format. To ease site navigation, access to important information, like that in reports, was embedded no more than two links from the homepage.

In this case, regulative institutions shaped the structuring of the Internet site's design process. Legal authority, invested in the commission chairman, led to the Website's development. More importantly, after the initiating decision was conveyed, staff members' understanding of the technology's potential reflected their understanding of regulative institutions. Evaluation criteria emphasized information provision requirements embedded in the regulatory framework. Rather than employing "state of the art" features, the Website ensured that users with limited access to new software or technology could view and retrieve information. By establishing the legal context, regulative institutions framed structures of domination embedded in the Website's design. The Website's design processes and outcome were influenced by OVERSIGHT's regulative environment.

\section{Case Two: Normative Institutions and Information Provision Over the Web}

Acting on values of the Reinventing Government movement (Frederickson, 1991), stakeholders pressured Florida agencies to reform basic business processes. For example, Florida Taxwatch, a watchdog organization, has emerged as an influential monitor of government spending. It has issued numerous reports identifying opportunities for the streamlining of public service provision. While honoring traditional commitments to open government, groups such as Taxwatch have argued that public agencies should provide more and better services. Reformers' successes are evident in new performance measurement standards. In 1994, the Florida legislature passed the Government Performance and Accountability Act. It required agencies to develop, report on, and apply performance measures to service delivery (Florida Taxwatch, 1999). In 1999, the legislature amended the Act to require that agencies provide unit cost information (Florida Taxwatch, 1999). By focusing attention on unit costs, stakeholders have increased pressure for realizing more effective business processes.

Shifts in normative institutions re-framed how agencies integrated new technologies. PROVIDER is a large state agency charged with notifying interested parties of requests for proposals (RFPs) and of regulatory changes. In the past, PROVIDER employees have had to collect, format, and share information in a weekly publication. Because statutes limited the cost per page of the publication (Florida Attorney General, 1997a), the agency could not fully recoup the high labor and production costs tied to the publication. To streamline production processes, PROVIDER moved from a printed standard to an electronic solution for delivering the publication. Electronic submissions have to conform to pre-specified standards for inclusion in the electronic document. Documents are then made available at the first of each week on a Website. Subscribers may download documents or view them through web browsers. By selecting an Internet-based solution, the agency shifted production costs to peer agencies and delivery costs to subscribers. By moving to an electronic solution, PROVIDER conformed to pressure to develop efficient and effective business processes. It is important to note that PROVIDER has not 
made a complete transition to an electronic publication. Because many citizens lack computer access, managers expressed a concern that all citizens would not be able to view the information. Due to these concerns, PROVIDER distributes both print and electronic versions of the document.

Competing normative institutions provided cultural legitimacy to providing both electronic and paper versions of the publication. Responding to shifting normative institutions, PROVIDER developed a system that streamlined service provision. By doing so, it reduced publication costs and eased stakeholders' access to information. Through the use of IT, the agency complied with normative institutions' emphasis on cost-effective service delivery. At the same time, PROVIDER's understanding of IT's limits were influenced by perceived obligations to provide access to information. Despite being less cost-effective, the agency used a paper-based alternative to ensure that a wide range of stakeholders could obtain copies of the documents. In this case, normative institutions influenced the structuring of how the agency perceived limits on the legitimate uses of electronic publications.

\section{Case Three: Cognitive Institutions and Website Implementation}

CONSERVE is a large non-profit environmental organization with over one million members in the United States (US) alone and is the largest private intemational organization of its type in the world. The nature of the organization is that of an information provider. Recently CONSERVE implemented a website. The website design involved representatives from every department in its planning, design, and implementation. Its features reflect cognitive institutions' influence on the organization.

The website was used to provide external and internal stakeholders information on the organization. Interviews with CONSERVE staff indicated that perceived task turnaround time dropped and that the use of Internet technology resulted in high performers doing more work. Professional staff was able to produce more in terms of both quantity and quality. This increase of information coupled with an increase in output can be explained through the use of cognitive institutions. Individuals with greater access to information can better determine the internal representation of their environment and increase their work output. As noted by Scott "social construction of actors also defines what they see as their interests" (1995, p. 43). In this case the increase in information allowed the actors (CONSERVE personnel) to better define what they saw as their interests (doing a better job).

The introduction of the website also radically changed the way the way CONSERVE handled the enforcement of rules and regulations. In the past rules and regulations were bound and distributed to each department. Due to the cumbersome process of having to manually look up a particular regulation enforcement was less stringent. The introduction of the website allowed increased and easier access to the rules and regulations. Consequently, enforcement increased. Easier access to information allowed individuals to better internalize the rules and regulations, which resulted in more widespread enforcement. This influenced members' perceptions of cognitive institutions on rule enforcement.

\section{IMPLICATIONS AND DIRECTIONS FOR FUTURE RESEARCH}

This paper has several important implications towards our understanding of technology in organizations. First, it suggests that scholars should attempt to identify the influence of institutions on the structuring of technologies. By identifying external sources, scholars may identify patterns of structure across industries and organizational fields. By doing so, studies may better inform our understanding of how technology influences organizations.

The paper also extends our understanding of how external institutions such as laws or professional values may influence the structuring of technologies. Laws constrain human action and the understanding of the range of possible actions. By framing how we intially perceive a technology, external institutions limit the range of possible applications of that technology. To fully understand IT as a social structure, more detailed research is needed to examine external institutions' influence within organizations.

For practitioners, this research suggests that attempts to sell or implement a technology need to be positioned in a manner consistent with an organization's institutional context. For example, when marketing a technology to a public agency, a firm would be well served to research not only legal issues, but also which institutions and social structures influence managerial decisions. By gaining a thorough understanding of how technology is structured, individuals will increase the likelihood of successful sales or implementation efforts.

As presented, the model reflects a limited view of how external structures interact with organization specific structures. A more comprehensive study might examine links between stakeholder perceptions, technology, and public agency activity across levels of government. Examining institutions' influence within public organizations should be perceived as a starting point for broader studies of technology's definition across sectors. Future research might explore how statutory reporting requirements influence decision-makers' IT selection and implementation within firms. Also, this study provided a limited view of how organizations' structures influence the development of institutions. Future research should examine how processes within a 
single organization or group of organizations contribute to broader social and industry-wide understanding and applications of technology.

\section{REFERENCES}

Anderson, K.V. and Danziger, J.N. (1995) "Information Technology and the Political World: The Impact of it on Capabilities, Interactions, Orientations and Values", International Journal of Public Administration, Vol. 18, pp 1693-1746.

Barley, S. R. (1986) "Technology as an Occasion for Structuring Evidence from Observations of CT Scanners and the Social Order of Radiology Departments", Administrative Science Quarterly, Vol. 31, pp 78-108.

Cats-Baril, W. and Thompson, R. (1995) "Managing Information Technology Projects in the Public Sector", Public Administration Review, Vol. 55, pp 559-566.

Caudle, S.L., Gorr, W.L. and Newcomer, K.E. (1991) "Key Information Systems Management Issues for the Public Sector”, MIS Quarterly, Vol. 15, pp 171-188.

Danziger, J.N., Dutton, W.H., Kling, R., and Kraemer, K.L. (1982) Computers in Politics, New York: Columbia University Press.

De Sanctis, G., and Poole, M.S. (1994) "Capturing the Complexity in Advanced Technology Use: Adaptive Structuration Theory", Organization Science, Vol. 5, pp 121-147.

Fletcher, D.S. and Taplin, I.M. (1999) "Organizational Evolution: The American Life Cycle", National Productivity Review, Vol. 18, pp 29-36.

Florida Attorney General (1997a) "Florida's Government in the Sunshine Law," Available On-Line: http://legal.firn.edu/sunshine/general.html

Florida Attorney General (1997b) "Most Frequently Asked Questions on Florida's Open Government Laws", Available On-Line: http://hegal.firn.edu/sunshine/faq.html

Florida Department of State (1997) "Mortham Announces Pilot Program for Voting on the Internet", Available On-Line: http://www.dos.state.fl.us/press/new/internetvoting.htm

Florida Taxwatch (1999) "PB2 -- "Diamond in the Rough" or Just A "Zirconium Bauble"?" Available On-Line: http://www.floridataxwatch.org/

Frederickson, G.H. (1991) "Comparing the Reinventing Government Movement to the New Public Administration", Public Administration Review, Vol. 56, pp 263-270.

Fligstein, N. (1990) The Transformation of Corporate Control, Cambridge: Harvard University Press.

Giddens, A., (1979) Central Problems in Social Theory: Action, Structure and Contradiction in Social Analysis, Berkeley, CA: University of California Press.

Globerman, S. and Vining, A.R. (1996) "A Framework for Evaluating the Government Contracting Out Decision with an Application for Information Technology", Public Administration Review, Vol. 56, pp 577-584.

Gore, A. (1993) The National Performance Review, Washington, D.C.: U.S. Government Printing Office.

Gurbaxani, V., \& Whang, S. (1991) "The Impact of Information Systems on Organizations and Markets", Communications of the ACM, Vol. 34, pp 59-73.

Hoffman, A.J. (1999) "Institutional evolution and change: Environmentalism and the U.S. Chemical Industry", Academy of Management Journal, Vol. 42, pp 451-371.

King, J.L., Gurbaxani, V., Kraemer, K.L., McFarlan, F.W., Raman, K.S., and Yap, C.S., (1994) "Institutional Factors in Information Technology Innovation", Information Systems Research, Vol. 5, pp. 139-169.

Kelman, S., (1990) Procurement and Public Management: The Fear of Discretion and Quality of Government Performance, Washington D.C.: AEI Press.

Kraemer, K.L., Anderson, K.V., and Perry, J.L. (1994) "Information Technology and Transitions in the Public Service: A Comparison of Scandinavia and the United States." International Journal of Public Administration, Vol. 17, pp 1871-1906.

Kraemer, K.L., King, J.L., Dunkle, D.E. and Lane, J.P. (1989) Managing Information Systems: Change and Control in Organizational Computing, San Francisco: Jossey-Bass.

Madden, M. and Miranda, R. (1998) "Contracting for Enterprise Financial Software: The Methodology of Parallel Negotiations", Government Finance Review, Vol. 14, pp 33-39.

Myers, M.M. (1994) "A Disaster for Everyone to See: An Interpretive Analysis of a Failed IS Project", Accounting, Management, and Information Technology, Vol. 4, pp 185-201.

Norris, D., and Kramer, K.L. (1996) "Mainframe Computing in American Cities: Myths and Realities," Public Administration Review, Vol. 56, pp 568-576.

Orlikowski, W.J., (1991) "Integrated Information Environment or Matrix of Control? The Contradictory Implications of Information Technology", Accounting, Management and Information Technology, Vol. 1, pp 9-42.

Orlikowski, W.J. (1992) "The Duality of Technology: Rethinking the Concept of Technology in Organizations," Organization Science, Vol. 3, pp 398-427. 
Osborne, D., and Gaebler, T. (1993) Reinventing Government, How the Entrepreneurial Spirit is Transforming the Public Sector, New York: Plume.

Perry, J.L. (1997) "Antecedents of Public Service Motivation", Journal of Public Administration Research and Theory, Vol. 7, pp 181-197.

Perry, J.L. and Wise, L.R. (1990) "The Motivational Bases of Public Service”, Public Administration Review, Vol. 50, pp 367-373.

Rainey, H., Backoff, R. and Levine, C. (1976) "Comparing Public and Private Organizations," Public Administration Review, Vol. 36, pp 233-244.

Scott, R.S. (1995) Institutions and Organizations, Thousand Oaks, CA: Sage

State of Florida Technology Office (1997) http://mail.irm.state.fl.us

Wynne, B. and Otway, H.J. (1983) "Information Technology, Power and Managers," Office, Technology, and People, Vol. 2, pp. 43-56. 